UDC 614.3:613.3

DOI: $10.21668 /$ health.risk/2020.3.04.eng

Research article

\title{
ESSENTIAL ELEMENTS AND STANDARDS FOR THEIR CONTENTS IN DRINKING WATER
}

\section{O.O. Sinitsyna, S.I. Plitman, G.P. Ampleeva, O.A. Gil'denskiol'd, T.M. Ryashentseva}

Federal Scientific Center of Hygiene named after F.F. Erisman, 2 Semashko Str., Mytishchi, 141014, Russian Federation

Certain essential and conditionally essential natural elements (selenium, chromium, iodine, molybdenum, cobalt, vanadium, fluorine, lithium, silicon, boron, and bromine) are standardized in terms of their contents in drinking water as per sanitary-toxicological parameters of adverse health effects.

Our research goal was to determine a contribution made by drinking water into supplying a human body with essential natural elements as well as to substantiate the necessity to update standards regarding these substances.

We applied calculation models for dose equivalents of essential elements MPC (maximum permissible concentration), MPC calculations for these substances basing on a necessary $20 \%$ contribution made by drinking water into reference doses, and calculation of non-carcinogenic health risks due to essential elements occurrence in specific drinking water sources with these elements being distributed into different groups as per similar effects produced on certain organs and systems in a body.

We took existing drinking water sources containing 6 essential elements with similar effects as an example and applied a procedure for assessing non-carcinogenic health risks.

Acting nickel and selenium MPC do not supply a body with an optimal daily intake whereas their determined MPC are not only harmless but also conform to the minimum necessary intake dose. At the same time neither acting lithium MPC nor its calculated one taking into account risk assessment based on internationally accepted reference doses doesn't provide the minimum necessary daily intake into a human body. When boron and vanadium are contained in drinking water in a concentration close to their MPC, then their $20 \%$ contribution into the reference dose is exceeded (71.4\% and $164.7 \%$ accordingly). Introduction of these essential elements with food can become a factor that determines non-carcinogenic risk level.

Key words: essential elements, MPC in drinking water, non-carcinogenic risks, reference doses, minimum necessary daily doses, nickel, selenium, lithium, boron, vanadium.

The valid Sanitary-Epidemiologic Rules ${ }^{1}$ contain standards for concentrations of substances that are essential and conditionally essential such as selenium, chromium, iodine, molybdenum, cobalt, vanadium, fluorine, lithium, silicon, boron, and bromine. Their maximum permissible concentrations in drinking water $\left(\mathrm{MPC}_{\text {d.w. }}\right)$ are fixed as per sanitarytoxicological parameters related to adverse health effects. In some cases their occurrence in drinking water is determined by natural quality of a water source $[1,2]$. And it is quite possible that water contains several elements in different concentrations. According to

(C) Sinitsyna O.O., Plitman S.I., Ampleeva G.P., Gil'denskiol'd O.A., Ryashentseva T.M., 2020

Oksana O. Sinitsyna - Doctor of Medical Sciences, Professor, Corresponding member of the Russian Academy of Sciences, acting Director of the Institute for Complex Problems of Hygiene, Head of the Department for Drinking Water Supply Hygiene and Water Protection, Chief researcher (e-mail: oxsin66@mail.ru; tel.: +7 (985) 304-34-44; ORCID: https://orcid.org/0000-0002-0241-0690).

Sof'ya I. Plitman - Doctor of Medical Sciences, Professor, Consultant at the Department for Drinking Water Supply Hygiene and Water Protection (e-mail: sofiyaplitman40@mail.ru; tel.:+7 (495) 686-29-05; ORCID: https://orcid.org/0000-0002-6466-9198).

Galina P. Ampleeva - Candidate of Medical Sciences, Senior researcher at the Department for Drinking Water Supply Hygiene and Water Protection (e-mail: voda420@fferisman.ru; tel.: +7 (495) 582-96-68; ORCID: https://orcid.org/0000-0001-8097-3344).

Ol'ga A. Gil'denskiol'd - Researcher at the Department for Drinking Water Supply Hygiene and Water Protection (e-mail: goa@fferisman.ru; tel.: +7 (495) 582-96-68; ORCID: https://orcid.org/0000-0002-4559-1663).

Tat'yana M. Ryashentseva - Junior researcher at the Department for Drinking Water Supply Hygiene and Water Protection (e-mail: ry-tat-m@yandex.ru; tel.: +7 (495) 582-96-68; ORCID: https://orcid.org/0000-0003-0899-3505).

${ }^{1}$ SER 2.1.4.1074-01 (last amended on April 7, 2010). Drinking water. Hygienic requirements to quality of water taken from centralized drinking water supply systems. Quality control. Hygienic requirements to providing safety of hot water supply systems. KODEKS: an electronic fund for legal and regulatory documents. Available at: http://docs.cntd.ru/document/901798042 (06.04.2020) (in Russian). 
available literature data ${ }^{2,3.4}$ underground water sources contain boron in concentrations reaching $0.46 \mathrm{mg} / \mathrm{L}$; bromine concentrations in them vary within $0.029-0.9 \mathrm{mg} / \mathrm{L}$; vanadium, from 0.0013 to $0.074 \mathrm{mg} / \mathrm{L}$; calcium, from 20 to $430 \mathrm{mg} / \mathrm{L}$; cobalt, from 0.0004 to $0.0074 \mathrm{mg} / \mathrm{L}$; silicon, from 3.7 to $24.2 \mathrm{mg} / \mathrm{L}$; lithium, $0.019-0.071 \mathrm{mg} / \mathrm{L}$; molybdenum, 0.001-0.021 $\mathrm{mg} / \mathrm{L}$; nickel, 0.0043-0.021 mg/L; selenium, $0.001-0.052 \mathrm{mg} / \mathrm{L}$; fluorine, $0.4-4.8 \mathrm{mg} / \mathrm{L}$; chromium, 0.0016-0.1 $\mathrm{mg} / \mathrm{L}$ [3-9]. Therefore, we can state that essential elements contents in potential and already exploited sources for communal and drinking water supply vary from levels being much lower than MPC to values that are more than 4 times higher than the hygienic standards, for example, for fluorine, bromine, and selenium.

Our research goal was to determine what role the drinking factor played in supplying a human body with essential elements of natural origin.

Data and methods. We used the following data in our research:

- basic information on contents of essential elements in water sources in the RF with their concentrations being standardized in drinking water as per sanitary-toxicological parameters related to adverse health effects;

- standards for essential elements contents in drinking water and food products;

- reference doses for essential elements at chronic oral introduction.

The following research techniques were applied: we calculated dose equivalents of
$\mathrm{MPC}_{\text {d.w. }}$ for essential elements standardized as per sanitary-toxicological parameters related to adverse health effects; MPC $_{\text {d.w. }}$ taking into account a $20 \%$ contribution made by the drinking factor into a reference dose for essential elements at chronic oral introduction; noncarcinogenic health risks caused by essential elements occurring in specific drinking water sources and differentiated as per similar effects produced on functional state of specific organs and systems.

Results and discussion. Given that essential elements perform certain functions related to regulating activity of metabolic systems and cellular genome apparatus, and a human body reacts to their occurrence not only in a dose that is toxic but also in case there is deficiency of such elements, it seems advisable to update standards fixed for them [2, 6, 10-13].

Several works have dwelled on an issue related to minimum essential quantities of elements that made drinking water physiologically adequate as it can be seen in the WHO report; their results have found their practical implementation in a regulatory document that fixes quality standards for bottled drinking water $^{5}[14-17]$. For example, these works substantiate minimum essential calcium and magnesium concentrations. At the same time, minimal water hardness (determined mostly by these two elements concentrations) is not fixed in the existing regulatory documents ${ }^{6}$, and the only standard for it concerns solely the upper permissible level ${ }^{7}$. As for publications on other

\footnotetext{
${ }^{2}$ L.P. Alekseeva. Geochemistry of underground ice and salty waters in the western Yakutia: thesis of the dissertation. ... for a Doctor of Geological and Mineral Sciences degree. Irkutsk, 2016, 233 p. (in Russian).

${ }^{3}$ F.R. Dreeva. Peculiarities of microelements prevalence in mountain rivers in Kabardino-Balkaria influenced by natural and anthropogenic sources: thesis of the dissertation ... for a Candidate of geographical sciences degree. Nalchik, 2019,130 p. (in Russian).

${ }^{4}$ Chudaev O.V. Geochemistry and conditions predetermining formations of contemporary hot mineral underground solutions in a zone where the Asian Continent meets the Pacific Ocean: of the dissertation. ... for a Doctor of Geological and Mineral Sciences degree. Vladivostok, 2002, 256 p. (in Russian).

${ }^{5}$ SER2.1.4.1116-02. Drinking water. Hygienic requirements to quality of bottled water. Quality control. Moscow, 2002, 22 p. (in Russian).

${ }^{6}$ SER 2.1.4.1074-01. (last amended on April 7, 2010). Drinking water. Hygienic requirements to quality of water taken from centralized drinking water supply systems. Quality control. Hygienic requirements to providing safety of hot water supply systems. KODEKS: an electronic fund for legal and regulatory documents. Available at: http://docs.cntd.ru/document/901798042 (06.04.2020) (in Russian).

${ }^{7}$ State Standard 27.61-84. Sources of centralized communal and drinking water supply. Hygienic and technical requirements and rules for choosing them. KODEKS: an electronic fund for legal and regulatory documents. Available at: http://docs.cntd.ru/document/gost-2761-84 (06.04.2020) (in Russian).
} 
essential elements being in shortage, they don't provide sufficient grounds for regulating their minimal essential concentrations in drinking water [18-21].

Theoretical and practical issues related to providing people with essential elements in necessary quantities are mostly dealt with by experts in nutrition hygiene ${ }^{8}$; they tend to neglect the drinking factor completely in spite of the WHO recommendations to create standards for chemicals contents in drinking water taking into account their introduction with food products ${ }^{9,10}[15,22-24]$. Moreover, the WHO Guidelines on drinking water quality, the $4^{\text {th }}$ edition ${ }^{11}$, recommend estimating a contribution made by the drinking factor into a reference dose at oral exposure to be equal to $20 \%$. Most experts believe the previously fixed $10 \%$ contribution is too conservative and obviously insufficient.

Data on probable pathologic states occurring in a human body and caused not only by excess quantities of essential elements standardized in dirking water as per sanitary-toxicological parameters related to adverse health effects but also by their deficiency (Table 1) indicate it is vital to take such elements into account when predicting probable health risks.

Our choice on essential elements to be considered in the present work is limited to those standardized in drinking water only as per sanitary-toxicological parameters related to adverse health effects; it is due to such elements as copper, zinc, and iron being regulated as per organoleptic parameters related to adverse health effects and belonging to the $3^{\text {rd }}$ and $4^{\text {th }}$ hazard category; according to the conventional health risk assessment methodology, these elements are not included into any sum- mation in case of their combined occurrence in drinking water.

The present work involved the following procedures:

- elements concentrations $(\mathrm{mg} / \mathrm{L})$ were recalculated into unified measurements with minimal essential daily introduction $(\mathrm{mg} / \mathrm{kg} /$ day $)$; the following constants were used in calculations: an adult's body weight is $60 \mathrm{~kg}$, consumed water volume is 2 liters (Table 3$)^{11}$;

- doses equivalent to essential elements MPC in drinking water were compared with minimal essential and reference ones (Table 3);

- apart from determining a contribution made by MPC dose equivalents into a reference dose, we determined doses with their contribution into a reference one being equal to $20 \%$. Minimal essential doses that were first recalculated into concentrations were compared with existing and calculated MPC (Table 3);

- doses equivalent to existing $\mathrm{MPC}_{\text {d.w. }}$. were compared with doses that corresponded to introduction with food (Table 4);

- calculated MPC that secured a $20 \%$ contribution made by the drinking factor into a reference dose, were compared with concentrations that secured $100 \%$ of minimal essential introduction as per a given essential element (Table 5);

- hazard indexes were calculated for existing $\mathrm{MPC}_{\text {d.w. }}$ taken for processing data on elements and their concentrations detected in a scenario source;

- an existing underground water source was taken as an example for calculating noncarcinogenic risks (as per hazard index) taking into account several essential elements occurring in water that were standardized as per sanitary-toxicological parameters related to

\footnotetext{
${ }^{8} \mathrm{MG}$ 2.3.1.2432-08. The standards for physiological needs in energy and nutrients for different population groups in the Russian Federation. KODEKS: an electronic fund for legal and regulatory documents. Available at: http://docs.cntd.ru/document/1200076084 (06.04.2020) (in Russian).

${ }^{9}$ V.A. Konyukhov. The methodology for assessing iodine deficiency risks for people living in Orenburg: the thesis of the dissertation. ... for a Doctor of Medical Sciences degree. Orenburg, 2004, 295 p. (in Russian).

${ }^{10}$ Tolmacheva N.V. Ecological and physiological substantiation for optimal concentrations of macro- and microelements in drinking water and nutrition rations: thesis of the dissertation. ... for a Doctor of Medical Sciences degree. Moscow, 2011, 116 p. (in Russian).

${ }^{11}$ Guidelines on drinking water quality, the $4^{\text {th }}$ edition. Geneva, The World Health Organization Publ., 2017,628 p. (in Russian).
} 
adverse health effects and differentiated as per similar effects produced on the kidneys. Calculations were performed as per a conventional domestic procedure supplemented with determining a contribution made by detected elements into minimal essential levels that provided proper functioning of a human body. Hazard index was compared with a calculated sum of detected elements concentrations to their MPC ratios ${ }^{11}$.

Table 1

Pathologies caused by deficiency and excess of essential and conditionally essential elements standardized in drinking water as per sanitary-toxicological parameters related to adverse health effects

\begin{tabular}{|c|c|c|}
\hline \multirow{2}{*}{ Element } & \multicolumn{2}{|c|}{ Changes in a human body in case of: } \\
\hline & deficient doses & excessive doses \\
\hline Lithium & $\begin{array}{l}\text { Bipolar disorders. Growing probability of pancreatic } \\
\text { diabetes, cardiovascular disorders, and hypertension } \\
\text { occurrence }\end{array}$ & $\begin{array}{l}\text { Neurologic and mental disorders, the } \\
\text { thyroid gland functioning inhibition, } \\
\text { renal failure }\end{array}$ \\
\hline Chromium & $\begin{array}{l}\text { Improper tolerance to dextrose, risks of reproductive } \\
\text { disorders in men }\end{array}$ & $\begin{array}{l}\text { Damage to liver, kidneys, and gastro- } \\
\text { intestinal tract functioning }\end{array}$ \\
\hline Selenium & $\begin{array}{c}\text { Improper protein formation by the liver, immune } \\
\text { status failure, pancreatic dysfunction. The symptoms } \\
\text { get only worse in case of fluorine, calcium, } \\
\text { and iodine deficiency }\end{array}$ & $\begin{array}{l}\text { Damage to the liver, } \\
\text { spleen, and skin }\end{array}$ \\
\hline Cobalt & $\begin{array}{c}\text { Blood making organs dysfunction, liver dysfunction, } \\
\text { heart rate dysfunction, damage to bone tissue. } \\
\text { The symptoms get only worse in case of fluorine } \\
\text { deficiency }\end{array}$ & $\begin{array}{l}\text { Damage to the endocrine, blood- } \\
\text { making, and cardiovascular system }\end{array}$ \\
\hline Molybdenum & Tachycardia, night blindness & $\begin{array}{l}\text { Damage to the kidneys, blood- } \\
\text { making and musculoskeletal systems }\end{array}$ \\
\hline Silicon & $\begin{array}{l}\text { Arthrosis. The symptoms get only worse in case of cal- } \\
\text { cium deficiency }\end{array}$ & $\begin{array}{l}\text { Damage to the kidneys and muscu- } \\
\text { loskeletal system }\end{array}$ \\
\hline Fluorine & $\begin{array}{l}\text { Caries, periodontal disease. The symptoms get only } \\
\text { worse in case of calcium deficiency }\end{array}$ & $\begin{array}{l}\text { Damage to the musculoskeletal } \\
\text { system }\end{array}$ \\
\hline Iodine & $\begin{array}{c}\text { Hypothyroidism, fetus pathologies in the } 1^{\text {st }} \text { trimester. } \\
\text { The symptoms get only worse in case of selenium, co- } \\
\text { balt, and calcium deficiency }\end{array}$ & Hyperthyrosis \\
\hline Boron & $\begin{array}{l}\text { Sex hormones imbalance, susceptibility to pancreatic } \\
\text { diabetes, osteoporosis development }\end{array}$ & $\begin{array}{l}\text { Damage to the liver, kidneys, } \\
\text { nervous system, and reproductive } \\
\text { function }\end{array}$ \\
\hline Bromine & Anemia, elevated risks of miscarriage & $\begin{array}{l}\text { Damage to the endocrine system, } \\
\text { blood-making system, and kidneys }\end{array}$ \\
\hline Vanadium & A drop in sugar contents in blood & $\begin{array}{l}\text { Damage to the kidneys, liver, and } \\
\text { blood-making organs }\end{array}$ \\
\hline Nickel & Dermatitis & $\begin{array}{c}\text { Damage to the liver, cardiovascular } \\
\text { and blood-making systems, gastroin- } \\
\text { testinal tract }\end{array}$ \\
\hline Calcium & $\begin{array}{l}\text { Osteoporosis, improper blood coagulability. The symp- } \\
\text { toms get only worse in case of selenium, silicon, iodine, } \\
\text { and fluorine deficiency }\end{array}$ & Alkalosis, hypercalcinemia \\
\hline
\end{tabular}

$\mathrm{N}$ o t e : the table is made up basing on data taken from the works $[1,11-13,16,18-21,25-31]$. 
Table 2

Parameters and criteria that characterize health risks caused by essential elements contents in water taken from a «scenario» drinking water source

\begin{tabular}{|l|c|c|c|c|c|c|}
\hline Elements & $\begin{array}{c}\text { Concentra- } \\
\text { tion in } \\
\text { water, } \mathrm{mg} / \mathrm{l}\end{array}$ & $\begin{array}{c}\text { Dose equivalent } \\
\text { of a concentration, } \\
\mathrm{mg} / \mathrm{kg} / \text { day* }\end{array}$ & $\begin{array}{c}\text { MPC } \\
\text { in water, } \\
\mathrm{mg} / \mathrm{l}\end{array}$ & $\mathrm{C} / \mathrm{MPC}$ & $\begin{array}{c}\text { Minimal essential } \\
\text { daily introduction, } \\
\mathrm{mg} / \mathrm{kg} / \mathrm{day}\end{array}$ & $\begin{array}{c}\text { \% of minimal } \\
\text { essential daily } \\
\text { introduction }\end{array}$ \\
\hline Lithium & 0.06 & 0.003 & 0.03 & 2 & 0.0014 & 214 \\
\hline Boron & 0.04 & 0.002 & 0.5 & 0.08 & 0.0028 & 71.4 \\
\hline Vanadium ** & 0.017 & 0.00085 & 0.1 & 0.1 & 0.00014 & 164.7 \\
\hline Chromium & 0.019 & 0.000006 & 0.05 & 0.38 & 0.0007 & 8 \\
\hline Nickel & 0.001 & 0.00003 & 0.02 & 0.05 & 0.0014 & 46.7 \\
\hline Selenium & 0.0039 & 0.0002 & 0.01 & 0.13 & 0.00042 & 47.6 \\
\hline Molybdenum & 0.005 & 0.00014 & 0.07 & 0.07 & 0.0007 & 20 \\
\hline
\end{tabular}

$$
\Sigma \mathrm{C} / \mathrm{MPC}=2.71
$$

Note :

* the value is calculated basing on exposure factors that are conventional for substantiating MPC in water according to MG 2.1.5.720-98 (60 kg body weight, $2 \mathrm{~L}$ daily water consumption $)^{12}$;

** means the substance belongs to the $3^{\text {rd }}$ hazard category and their concentrations ratio to MPC is not included into the calculation.

Table 3

Properties of essential elements standardized in drinking water as per sanitary-toxicological parameters related to adverse health effects

\begin{tabular}{|l|c|c|c|c|}
\hline \multicolumn{1}{|c|}{ Elements } & $\begin{array}{c}\text { MPC, } \mathrm{mg} / \mathrm{L} \\
\text { in water }\end{array}$ & $\begin{array}{c}\text { Minimal essential } \\
\text { dose, } \mathrm{mg} / \mathrm{kg} / \mathrm{day}^{1}\end{array}$ & $\begin{array}{c}\mathrm{RfD}, \\
\mathrm{mg} / \mathrm{kg} / \text { day }^{2}\end{array}$ & $\begin{array}{c}\mathrm{MPC}_{\text {d.w. }} \text { dose } \\
\text { equivalent } \mathrm{mg} / \mathrm{kg} / \text { day }\end{array}$ \\
\hline Boron & 0.5 & 0.0024 & 0.2 & 0.016 \\
\hline Bromine & 0.2 & 0.0059 & 1.0 & 0.0066 \\
\hline Vanadium & 0.1 & 0.00012 & 0.007 & 0.0032 \\
\hline Iodine & 0.12 & $0.00059 / 0.002^{3}$ & 0.017 & 0.004 \\
\hline Cobalt & 0.1 & 0.0004 & 0.02 & 0.0032 \\
\hline Lithium & 0.03 & 0.0012 & 0.02 & 0.00098 \\
\hline Molybdenum & 0.07 & $0.00059 / 0.008^{3}$ & 0.02 & 0.0023 \\
\hline Nickel & 0.02 & 0.00112 & 0.02 & 0.00066 \\
\hline Selenium & 0.01 & $0.00035 / 0.002^{3}$ & 0.005 & 0.00032 \\
\hline Fluorine & 1.0 & $0.0178 / 0.021$ & 0.06 & 0.032 \\
\hline Chromium & 0.05 & $0.00059 / 0.0025$ & 0.005 & 0.0016 \\
\hline
\end{tabular}

Note:

${ }^{1}$ are average data taken from the works ${ }^{8}[11,13,24]$;

${ }^{2}$ are data taken from Guide 2.1.10.1920-0 $4^{13}$;

${ }^{3}$ means a value is recalculated into doses per $1 \mathrm{~kg}$ body weight.

${ }^{12}$ MG 2.1.5.720-98. Substantiation of hygienic standards for chemicals contents in water taken from water objects aimed for communal and drinking water supply: Methodical guidelines. Approved by the RF Chief Sanitary Inspector on October 15, 1998. Sanitary rules and standards and State standards. Reference database. Available at: https://www.snip-info.ru/index.html (06.04.2020) (in Russian).

${ }^{13}$ Guide 2.1.10.1920-04 Guide on assessing population health risks under exposure to chemical that pollute the environment. KODEKS: an electronic fund for legal and regulatory documents. Available at: http://docs.cntd.ru/document/1200037399 (06.04.2020) (in Russian). 
Comparing contributions made by dose equivalents of $\mathrm{MPC}_{\text {d.w. }}$ and doses consumed with food into reference doses

\begin{tabular}{|l|c|c|c|c|c|}
\hline Elements & $\begin{array}{c}\mathrm{MPC}_{\text {d.w. dose }} \\
\text { equivalent } \\
\mathrm{mg} / \mathrm{kg} / \mathrm{day}\end{array}$ & $\begin{array}{c}\text { Dose consumed } \\
\text { with food, } \\
\mathrm{mg} / \mathrm{kg} / \mathrm{day}\end{array}$ & $\begin{array}{c}\text { Reference } \\
\text { dose, } \\
\mathrm{mg} / \mathrm{kg} / \mathrm{day}\end{array}$ & $\begin{array}{c}\mathrm{MPC}_{\text {d.w. }} \text { dose } \\
\text { equivalent contribu- } \\
\text { tion into RfD, \% }\end{array}$ & $\begin{array}{c}\text { Food introduc- } \\
\text { tion contribution } \\
\text { into RfD, \% }\end{array}$ \\
\hline Boron & 0.016 & 0.0018 & 0.2 & 8 & 0.9 \\
\hline Vanadium & 0.0032 & 0.0006 & 0.007 & 45.7 & 8.5 \\
\hline Cobalt & 0.0032 & 0.004 & 0.02 & 16.5 & 20 \\
\hline Lithium & 0.00098 & 0.003 & 0.02 & 5.0 & 15 \\
\hline Iodine & 0.004 & 0.003 & 0.017 & 23.5 & 17.9 \\
\hline Molybdenum & 0.0023 & 0.0028 & 0.02 & 11.5 & 14.0 \\
\hline Selenium & 0.00032 & 0.002 & 0.005 & 6.4 & 40 \\
\hline Fluorine & 0.032 & 0.025 & 0.06 & 54 & 41.6 \\
\hline Chromium & 0.0016 & 0.002 & 0.005 & 32 & 40 \\
\hline
\end{tabular}

Table 5

Calculated concentrations that secure a $20 \%$ contribution made by the drinking factor into reference doses and $100 \%$ minimal essential introduction of an essential element

\begin{tabular}{|l|c|c|c|}
\hline \multicolumn{1}{|c|}{ Elements } & $\begin{array}{c}\text { MPC, } \\
\mathrm{mg} / \mathrm{L}\end{array}$ & $\begin{array}{c}\text { Calculated MPC that secures 20 \% } \\
\text { contribution into RfD, mg/L }\end{array}$ & $\begin{array}{c}\text { Calculated MPC that secures } 100 \% \\
\text { minimal essential dose, } \mathrm{mg} / \mathrm{L}\end{array}$ \\
\hline Boron & 0.57 & 1.4 & 0.072 \\
\hline Bromine & 0.2 & 0.06 & 0.2 \\
\hline Vanadium & 0.1 & 0.05 & 0.0037 \\
\hline Iodine & 0.125 & 0.13 & 0.02 \\
\hline Cobalt & 0.1 & 0.14 & 0.0083 \\
\hline Lithium & 0.03 & 0.014 & 0.041 \\
\hline Molybdenum & 0.07 & 0.14 & 0.02 \\
\hline Nickel & 0.02 & 0.14 & 0.041 \\
\hline Selenium & 0.01 & 0.034 & 0.011 \\
\hline Fluorine & 1.0 & 0.42 & 0.62 \\
\hline Chromium & 0.05 & 0.032 & 0.029 \\
\hline
\end{tabular}

It was established that existing MPC of such essential elements as fluorine, chromium, cobalt, boron, vanadium, iodine, molybdenum, and bromine could provide a human body with minimal essential introduction.

In case boron and vanadium are contained in water in concentrations equal to their MPC, their contributions into a reference dose will be higher than $20 \%(71.4 \%$ and $164.7 \%$ accordingly). Introduction of these essential elements with food products can be a factor that might determine non-carcinogenic risks.

Calculated $\mathrm{MPC}_{\text {d.w }}$ for nickel and selenium are more optimal as compared with their existing ones as they not only secure safety but also provide minimal essential introduction of these essential elements.

Both existing and calculated standards for lithium do not provide minimal essential introduction of the elements into a body.

There were calculations performed to assess non-carcinogenic health risks caused by use of the selected "scenario» water source; the results revealed the following (Table 6) [3].

Non-carcinogenic risks regarding renal pathology occurrence were assessed as acceptable and amounted to 0.8925 [31]. However, quality of water taken from the examined 
Parameters and criteria that characterize health risks caused by element structure of water taken from the «scenario» drinking water source

\begin{tabular}{|l|c|c|c|c|c|c|}
\hline Elements & $\begin{array}{c}\text { Concentra- } \\
\text { tion, mg/L }\end{array}$ & $\begin{array}{c}\text { Dose equiva- } \\
\text { lent for con- } \\
\text { centration, } \\
\mathrm{mg} / \mathrm{kg} / \mathrm{day}\end{array}$ & HQ & $\begin{array}{c}\text { Minimal essen- } \\
\text { tial daily intro- } \\
\text { duction, } \\
\mathrm{mg} / \mathrm{kg} / \text { day }\end{array}$ & $\begin{array}{c}\text { \% to which detected } \\
\text { concentration } \\
\text { provides minimal } \\
\text { essential daily } \\
\text { introduction }\end{array}$ & C/MPC \\
\hline Lithium & 0.06 & 0.017 & 0.85 & 0.0014 & 80 & 2 \\
\hline Boron & 0.04 & 0.001 & 0.005 & 0.0028 & 35.7 & 0.2 \\
\hline Vnadium $^{\mathrm{x}}$ & 0.017 & 0.0005 & 0.07 & 0.00014 & 350 & 0.085 \\
\hline Chromium $^{\mathrm{x}}$ & 0.00019 & 0.0006 & 0.001 & 0.0007 & 7.8 & 0.0038 \\
\hline Nickel $^{\mathrm{x}}$ & 0.001 & 0.003 & 0.0015 & 0.0014 & 2.14 & 0.05 \\
\hline Selenium & 0.0039 & 0.0001 & 0.028 & 0.00042 & 25 & 0.13 \\
\hline $\begin{array}{l}\text { Molybde- } \\
\text { num }\end{array}$ & 0.005 & 0.00014 & 0.007 & 0.0007 & 20 & 0.25 \\
\hline
\end{tabular}

$\mathrm{HI}=0.8925$

$\Sigma \mathrm{C} / \mathrm{MPC}=2.74$

Note:

${ }^{\mathrm{x}}$ means a substance belongs to the $3^{\text {rd }}$ hazard category and their concentrations ratio to MPC is not included into the calculation.

water source can't be seen as acceptable for health as per chromium and nickel concentrations as dose equivalents of these elements concentrations are significantly lower than deficient ones and amount to $0.0006 \mathrm{mg} / \mathrm{kg} /$ day for chromium and $0.003 \mathrm{mg} / \mathrm{kg} /$ day for nickel whereas a deficient dose for both elements amounts to $0.028 \mathrm{mg} / \mathrm{kg} /$ day.

This fact should be taken into account when social and hygienic monitoring is performed; great attention should be paid to pathologies caused by relevant elements being in shortage (reproductive function disorder in men and tolerance to dextrose in people with the drinking factor being predominant for them among other ones influencing prevalence of analogue disorders in a body).

Parallel calculations performed as per the conventional procedure for estimating total effects produced by substances standardized as per sanitary-toxicological parameters related to adverse health effects ${ }^{8,9}$ indicate that an acceptable hygienic standard for all the substances that occur in the examined water source is violated as the total sum of all the detected concentrations to their MPC ratios amounts to 2.74 .
It doesn't seem sufficient to look for a solution to an issue related to essential elements shortage primarily within nutrition hygiene frameworks as it belittles a role played by the drinking factor in providing a body with them. Nutrition hygiene practically neglects the fact that water is always used in food processing and cooking with consumed volumes varying from 1,000 to 4,000 liters per one ton of food products, and up to $23 \%$ essential elements contained in food products are lost due to thermal treatment $[22,31]$. Given that, the WHO recommendation to increase a contribution made by the drinking factor into reference doses from $10 \%$ to $20 \%$ is quite well-timed. A way to resolve the issue may be found in wider use of drinking water sources with water containing essential elements in quantities sufficient to cover any deficiency in their essential consumption [24-31].

\section{Conclusions:}

1. In case fluorine, chromium, cobalt, boron, vanadium, iodine, molybdenum, and bromine are contained in water taken from a drinking water source in concentrations being equal to their existing MPC in water, it pro- 
vides their minimal essential introduction into a human body.

2 . When assessing water sources that contain nickel and selenium, it is advisable to apply calculated MPC that provide their minimal essential introduction into a human body whereas existing MPC for these elements can't secure this effect.

3. When selecting a drinking water source, it seems advisable to give preference to those with natural contents of essential elements providing their minimal essential introduction into a human body that corresponds to its physiological needs.

Funding. The research was not granted any sponsor support.

Conflict of interests. The authors declare there is no any conflict of interests.

\section{References}

1. Avtsyn A.P., Zhavoronkov A.A., Strochkova L.S. Mikroelementozy cheloveka [Human microelements imbalances]. Moscow, Meditsina Publ., 1991, 496 p. (in Russian).

2. Krainev V.S. Ryzhenko B.N., Shvets V.M. Geokhimiya podzemnykh vod. Teoreticheskie, prikladnye i ekologicheskie aspekty [Underground waters geochemistry. Theoretical, applied, and ecological aspects]. Moscow, Nauka Publ., 2004, 677 p. (in Russian).

3. Gorbachev I.V., Puzanov A.V. Mikroelementy v poverkhnostnykh i podzemnykh vodakh v basseinakh malykh rek severo-zapada Altaya [Microelements in surface and underground waters in small river basins in north-western Altai]. Mir nauki, kul'tury i obrazovaniya, 2008, no. 1, pp. 23-26 (in Russian).

4. Kremleva T.A., Moiseenko T.I., Khoroshavin V.Yu. [et al.]. Geokhimicheskie osobennosti prirodnykh vod Zapadnoi Sibiri: mikroelementnyi sostav [Geochemical peculiarities of natural waters in the West Siberia: microelement structure]. Vestnik Tyumenskogo GU, 2012, no. 12, pp. 80-89 (in Russian).

5. Loginova E.V. Gidrologiya. Kurs lektsii [Hydrology. Lectures]. Minsk, BGU Publ., 2011, 300 p. (in Russian).

6. Mishukova T.T. Determination of trace elements in drinking waters of Orenburg oblast. Vestnik Orenburgskogo GU, 2015, no. 10, pp. 303-308 (in Russian).

7. Sklyarova O.A., Sklyarov E.V. Concentration of trace elements in small lakes of the ingoda basin (Chita region, Russia). Geologiya i geofizika, 2012, no. 12, pp. 1722-1734 (in Russian).

8. Shakhmatov S.A. Kachestvo podzemnykh vod territorii raionov Krasnoyarskogo kraya [Underground waters quality in Krasnoyarsk region]. Vestnik Krasnoyarskogo GAU, 2013, no. 5, pp. 154-156 (in Russian).

9. Yanin E.P. Osobennosti khimicheskogo sostava i ekologo-gigienicheskaya rol' pit'evykh vod v usloviyakh prirodno-tekhnogennoi biogeokhimicheskoi provintsii [Peculiarities of chemical structure and ecological and hygienic role of drinking water in a natural-technogenic biogeochemical province]. Ekologicheskaya ekspertiza, 2012, no. 2, pp. 64-91 (in Russian).

10. Dakhova E.V., Tselykh E.D. Influence of drinking water in the state of some human body systems. Uchenye zapiski TGU, 2011, vol. 6, no. 4, pp. 105-109 (in Russian).

11. Oberlis D., Kharland B.F. Biologicheskaya rol' makro- i mikrokomponentov u cheloveka i zhivotnykh [Biological role played by macro- and micro-components in people and animals]. SanktPeterburg, Nauka Publ., 2008, 544 p. (in Russian).

12. Rodionova L.V. Physiological role of macro- and microelements (literature review). Byulleten' VSNTs SO RAMN, 2005, no. 6, pp. 195-198 (in Russian).

13. Skal'nyi A.V., Rudakov I.A. Bioelementy v meditsine [Bioelements in medicine]. Moscow, Mir Publ., 2004, 272 p. (in Russian).

14. Kondratyuk V.A. Mikroelementy, znachimost' dlya zdorov'ya v pit'evoi vode maloi mineralizatsii [Microelements, their significance for health in drinking water with low mineralization]. Gigiena $i$ sanitariya, 1989, no. 2, pp. 81-82 (in Russian).

15. Lyutai G.F. Vliyanie mineral'nogo sostava pit'evoi vody na zdorov'e naseleniya [Influence exerted by mineral structure of drinking water on population health]. Gigiena i sanitariya, 1992, no. 1, pp. 13-15 (in Russian). 
16. Plitman S.I., Novikov Yu.V., Tulakina N.V. [et al.]. K voprosu korrektsii standartov po demineralizovannoi vode $\mathrm{s}$ uchetom zhestkosti pit'evoi vody [On adjusting standards for mineralized water taking into account drinking water hardness]. Gigiena i sanitariya, 1989, no. 7, pp. 7-11 (in Russian).

17. Rakhmanin Yu.A., Mikhailova R.I., Kir'yanova L.F., Sevost'yanova E.M., Ryzhova I.N. Itogi i perspektivy issledovanii $\mathrm{v}$ oblasti pit'evoi vody [Results and prospects of research on drinking water]. Itogi i perspektivy nauchnykh issledovanii po problemam ekologii cheloveka i gigieny okruzhayushchei sredy. Moscow, 2001, pp. 97-105 (in Russian).

18. Koval'skii V.V. Rol' ioda i kobal'ta $\mathrm{v}$ deyatel'nosti shchitovidnoi zhelezy $\mathrm{v}$ usloviyakh biogeokhimicheskikh provintsii s nedostatkom ioda i kobal'ta [Role played by iodine and cobalt in the thyroid gland functioning in biogeochemical provinces with iodine and cobalt deficiency]. Mikroelementy $v$ sel'skom khozyaistve i meditsine. Moscow, 1972, pp. 450-465 (in Russian).

19. Tarantin A.V., Zemlyanova M.A. Vanadium essential role and toxic effects. Ekologiya cheloveka, 2015, no. 12, pp. 59-62 (in Russian).

20. Troshina E.A. About deficiency and excess in iodine in human. Klinicheskaya i eksperimental'naya tireoidologiya, 2010, no. 4, pp. 9-16 (in Russian).

21. Yanin E.P. Biogeokhimicheskaya rol' i ekologo-gigienicheskoe znachenie ftora [Fluorine: biogeochemical role and ecological and hygienic significance]. Problemy okruzhayushchei sredy i prirodnykh resursov, 2009, no. 4, pp. 20-108 (in Russian).

22. Druzhinin P.V., Novikov L.F., Lysenkov Yu.A. Mir nauki. Moscow, 2010, 339 p. (in Russian).

23. Lysikov Yu.A. Rol' i fiziologicheskie osnovy obmena makro- i mikroelementov v pitanii cheloveka [Role and physiological bases of macro- and microelements metabolism in human nutrition]. Eksperimental'naya i klinicheskaya gastroenterologiya, 2009, no. 2, pp. 120-131 (in Russian).

24. Rebrov V.G., Gromova O.A. Vitaminy, makro- i mikroelementy [Vitamins, macro- and microelements]. Moscow, GOETAR-Media Publ., 2008, 960 p. (in Russian).

25. Baranovskaya N.V., Perminova T.A. Biogeochemical features of the accumulation of bromine in the human body (example of Tomsk region). Vestnik OmGU, 2016, no. 3, pp. 155-161 (in Russian).

26. Galenko-Yaroshevskii P.A. Vliyanie litiya na deyatel'nost' serdechno-sosudistoi sistemy [Influence exerted by lithium on the cardiovascular system functioning]. Farmakologiya i toksikologiya, 1986, no. 5, pp. 115-117 (in Russian).

27. Zinina O.T. Vliyanie nekotorykh tyazhelykh metallov i mikroelementov na biokhimicheskie protsessy $\mathrm{v}$ organizme cheloveka [Influence exerted by certain heavy metals and microelements on biochemical processes in a human body]. Izbrannye voprosy sudebno-meditsinskoi ekspertizy, 2001, no. 4, pp. 99-105 (in Russian).

28. Mazaev V.T., Shlepnina T.G. Otsenka stepeni sanitarnoi opasnosti soedinenii kremniya v prirodnykh ipit'evykh vodakh [Assessment of sanitary threats created by silicon compounds in natural and drinking water]. Vodosnabzhenie i sanitarnaya tekhnika, 2011, no. 5, pp. 37 (in Russian).

29. Retstina S.V. Rol' khroma v organizme cheloveka [Chromium and its role in a human body]. Vestnik RUDN, 2009, no. 4, pp. 50-55 (in Russian).

30. Reshetnik L.A., Parfenova E.O. Selen v zhizni cheloveka i zhivotnykh [Selenium in life of people and animals]. In: L.P. Nikitina ed. Moscow, VINITI Publ., 1995, 242 p. (in Russian).

31. Shvetsov A.A., Bulanov E.A. Water consumption at catering establishments and a way of its reduction. Tekhniko-tekhnologicheskie problemy servisa, 2015, vol. 32, no. 2, pp. 55-59 (in Russian).

Sinitsyna O.O., Plitman S.I., Ampleeva G.P., Gil'denskiol'd O.A., Ryashentseva T.M. Essential elements and standards for their contents in drinking water. Health Risk Analysis, 2020, no. 3, pp. $29-37$. DOI: 10.21668/health.risk/2020.3.04.eng

Received: 07.08.2020

Accepted: 17.08.2020

Published: 30.09 .2020 